Kredo 4 (2021)
KREDO: Jurnal Ilmiah Bahasa dan Sastra
Terakreditasi Sinta 4 berdasarkan Keputusan
Direktorat Jenderal Penguatan Riset dan
Pengembangan, Kementerian Riset, Teknologi dan
Pendidikan Tinggi Republik Indonesia
Nomor: 23/E/KPT/2019.08 Agustus 2019
https://jurnal.umk.ac.id/index.php/kredo/index

\title{
BENTUK KESANTUNAN TUTURAN PENDIDIK DENGAN PESERTA DIDIK DALAM INTERAKSI PEMBELAJARAN
}

\author{
Muzayyanatun Nisa'1, Mila Roysa', Mohammad Kanzunnudin ${ }^{3}$ \\ Muzayyanatun.nisa2013@gmail.com
}

Universitas Muria Kudus, Indonesia

\section{Info Artikel Sejarah Artikel \\ Diterima \\ 12 Februari 2021 \\ Disetujui \\ 3 Maret 2021 \\ Dipublikasikan \\ 7 April 2021}

\section{Keywords}

Politeness, Teacher speech, Student

\section{Kata Kunci}

Kesantunan, Tuturan pendidik, Peserta didik
: Abstract

This research describes the politeness of the teacher's speech in learning at 'Aisyiyah Bustanul Athfal XIV Kindergarten Pasuruhan Lor Kudus. Language politeness still minimal attention. This makes the role of teacher very important in improving language politeness. This research is a qualitative research, describes the form of politeness in the learning interaction between teachers and students. The subject in this research is a teacher. Furthermore, the object of this research is all dialogues in the form of words, phrases and / or sentences spoken by the teacher during learning, whether it is a violation or obedience to the maxims of politeness. Data collection based on observation, interviews, and documentation. Furthermore, the data were analyzed and concluded. Validity checking of the data using pragmatic validity. Pragmatic validity aims to measure how well the method is used in various condition. This results showed that language politeness of teachers : towards students obeyed the principles of politeness, namely based on the maxim of wisdom, the maxim of generosity, the maxim of sympathy and the maxim of consensus. Teachers in interacting with students tend to use simple vocabulary, easy to understand and not high pitched. The impact of politeness in teacher's language includes the development of students who are able to apply : politeness to language. Such as apologizing when wrong, tend to obey when ordered, can make students more polite and respect others.

\section{ABSTRAK}

Penelitian ini bertujuan mendeskripsikan kesantunan tuturan pendidik dalam pembelajaran di TK 'Aisyiyah Bustanul Athfal XIV Pasuruhan Lor Kudus. Kesantunan berbahasa masih minim diperhatikan. Hal ini menjadikan peran pendidik sangat penting dalam meningkatkan kesantunan berbahasa. Penelitian ini merupakan penelitian kualitatif yang bertujuan untuk mendeskripsikan bentuk kesantunan dalam interaksi pembelajaran antara pendidik dengan peserta didik. Subjek penelitian ini yakni seorang pendidik. Selanjutnya, objek penelitian ini yakni semua dialog yang berupa kata, frasa, dan atau kalimat yang dituturkan oleh pendidik pada saat pembelajaran baik itu pelanggaran atau pematuhan maksim-maksim kesantunan. Pengumpulan data dilakukan dengan observasi, wawancara, dan dokumentasi. Selanjutnya data dianalisis dan disimpulkan. Pemeriksaan/pengecekan keabsahan data menggunakan validitas pragmatis. Validitas pragmatis bertujuan untuk mengukur seberapa baik metode yang digunakan dalam berbagai keadaan. Hasil penelitian menunjukkan bahwa bentuk kesantunan berbahasa pendidik terhadap peserta didik mematuhi prinsip-prinsip kesantunan yakni berdasar pada maksim kearifan, maksim kedermawanan, maksim kesimpatisan dan maksim permufakatan. Pendidik dalam berinteraksi dengan peserta didik, cenderung menggunakan kosakata yang sederhana, mudah dipahami serta tidak bernada tinggi. Dampak dari kesantunan berbahasa pendidik di antaranya yakni perkembangan peserta didik yang mampu mengaplikasikan kesantunan berbahasa. Seperti halnya meminta maaf ketika salah, cenderung patuh saat diperintah, dapat menjadikan peserta didik lebih sopan serta menghargai orang lain. 


Kredo 4 (2021)
KREDO: Jurnal Ilmiah Bahasa dan Sastra
Terakreditasi Sinta 4 berdasarkan Keputusan
Direktorat Jenderal Penguatan Riset dan
Pengembangan, Kementerian Riset, Teknologi dan
Pendidikan Tinggi Republik Indonesia
Nomor: 23/E/KPT/2019. 08 Agustus 2019
https://jurnal.umk.ac.id/index.php/kredo/index

\section{PENDAHULUAN}

Bahasa merupakan alat komunikasi antarmanusia dalam kehidupan bermasyarakat. Bahasa berupa bunyi ujar yang dihasilkan oleh alat ucap manusia diperkuat dengan gerak-gerak badaniah yang nyata. Bahasa mencakup dua bidang, berupa bunyi vokal yang dihasilkan oleh alat ucap manusia merangsang alat pendengar kita-- diserap panca indera dan memiliki isi atau arti yang terkandung di dalamnya-- menyebabkan reaksi atau tanggapan dari orang lain (Keraf, 1973: 2).

Kehidupan manusia tidak pernah lepas dari komunikasi. Dalam berkomunikasi baik lisan maupun tulis bisa saja menimbulkan dua dampak yakni positif dan juga negatif. Maka, diperlukan pemahaman dan pengetahuan yang baik mengenai kaidah penggunaan bahasa dalam berkomunikasi.

Bersikap santun merupakan salah satu budaya Indonesia yang patut untuk diterapkan dalam setiap komunikasi. Baik itu berkomunikasi dengan orang yang lebih tua atau teman sebaya. Setiap pembicaraan yang dituturkan seseorang merupakan cerminan perilaku orang tersebut. Dikatakan santun apabila bertutur halus, dan dianggap tidak santun apabila bertutur kasar.

Proses pemerolehan bahasa merupakan aspek yang sangat penting. Dalam proses ini, hal utama yang harus diperhatikan yakni kesantunan. Kesantunan dalam berkomunikasi dan berinteraksi antarindividu maupun kelompok dapat mengarahkan dan membina peserta didik untuk mencapai kesesuaian kesantunan berbahasa.

Pengajaran bahasa pada Pendidikan Anak Usia Dini (PAUD) merupakan salah satu cara untuk mengembangkan seluruh potensi yang dimiliki anak usia dini. Anak usia tersebut dipandang memiliki karakteristik yang berbeda dengan anak usia di atasnya. Dengan karakteristik yang berbeda, perilaku keberbahasaannya juga berbeda.

Proses pendidikan pada anak usia dini pada hakikatnya adalah upaya memfasilitasi perkembangan yang sedang terjadi pada diri anak utamanya perkembangan dalam memperoleh bahasa. Perkembangan pemerolehan bahasa anak usia dini berkaitan dengan peningkatan kemampuan anak untuk mengenal dirinya dan berinteraksi dengan lingkungannya seiring pertumbuhan fisik yang dialami.

Penelitian ini terkait dengan kesantunan pendidik dalam pembelajaran anak usia dini. Dampak kesantunan berbahasa seorang pendidik sangat berpengaruh terhadap peserta didik. Sejatinya, tuturan seorang pendidik merupakan wujud dari pendidikan itu sendiri. Pendidikan ditopang atas keilmuan dan keteladanan. Aspek keteladanan yang tercermin dari cara berbicara dan berbahasa 


Kredo 4 (2021)
KREDO: Jurnal Ilmiah Bahasa dan Sastra
Terakreditasi Sinta 4 berdasarkan Keputusan
Direktorat Jenderal Penguatan Riset dan
Pengembangan, Kementerian Riset, Teknologi dan
Pendidikan Tinggi Republik Indonesia
Nomor: 23/E/KPT/2019.08 Agustus 2019
https://jurnal.umk.ac.id/index.php/kredo/index

sangat dibutuhkan untuk mengasah pola bicara dan pemerolehan bahasa anak usia dini. Dintinjau dari teori perkembangan kognitif dalam (Subyantoro, 108: 2008) pemerolehan kosakata anak berbeda-beda. Perbedaan tersebut dipengaruhi oleh tingkat kecerdasan yang berasal dari tiap-tiap individu itu sendiri. Dapat dipahami bahwa proses penguasaan kosakata anak melibatkan kemampuan atau kepandaian dalam memahami tiap kosakata yang didengarnya.

Secara linguistik, kesantunan dalam pemakaian tuturan imperatif bahasa Indonesia sangat ditentukan oleh muncul atau tidaknya ungkapan-ungkapan penanda kesantunan. Macam-macam penanda kesantunan diantaranya sebagai berikut: tolong, mohon, silakan, mari, ayo biar, coba, harap, hendaknya, hendaklah, sudi kiranya, sudilah kiranya, sudi apalah kiranya.

Berkaitan dengan pemahaman dan penguasaan kosakata, kesantunan pendidik di sekolah sangat berpengaruh bagi peserta didik. Pendidik sebagai pengganti orang tua atau orang tua kedua ketika di sekolah. Hendaknya seorang pendidik PAUD senantiasa berkomunikasi secara baik dengan peserta didiknya. Meskipun teori kesantunan belum tentu menjadi tolok ukur dalam kesantunan berbahasa, akan tetapi mampu menjadi padoman agar masyarakat pada umumnya dapat menghargai mitra tuturnya.

Tujuan dari kesantunan berbahasa dalam pembelajaran di taman kanak-kanak 313 | Jurnal Kredo

Vol. 4 No. 22021 yakni, untuk memberikan rangsangan peserta didik agar dapat berkomunikasi secara santun. Selain itu, dapat meningkatkan penguasaan bahasa serta mampu mengefektifkan penggunaannya menjadi lebih komunikatif. Untuk mengaplikasikan kesantunan dalam berbahasa di lingkungan sekolah, anak usia dini sangat membutuhkan kehadiran pendidik yang senantiasa berbahasa santun utamanya di sekolah.

Demikian pula yang dikemukakan oleh Zamani, dkk (2011:35) bahwa tujuan dari kesantunan, termasuk kesantunan berbahasa yakni membuat suasana interaksi lebih menyenangkan, tidak mengancam muka, dan efektif. Namun, Nurjamily (2015) mengutarakan bahwa seorang penutur bahasa Indonesia saat ini, kurang memerhatikan maksim kesantunan berbahasa. Hal ini dikarenakan terbatasnya pengetahuan penutur yang meliputi beberapa faktor yakni, (1) prinsip sopan santun dalam berbahasa; (2) prinsip kerjasama dalam berbahasa; dan (3) konteks berbahasa.

Berdasarkan hasil wawancara dan observasi yang dilaksanakan pada April 2019 di TK 'Aisyiyah Bustanul Athfal XIV Pasuruhan Lor Kudus, dapat disimpulkan bahwa kesantunan seorang pendidik memiliki peran besar agar dapat membentuk kesantunan berbahasa peserta didik. Dapat disimpulkan pula bahwa 


Kredo 4 (2021)
KREDO: Jurnal Ilmiah Bahasa dan Sastra
Terakreditasi Sinta 4 berdasarkan Keputusan
Direktorat Jenderal Penguatan Riset dan
Pengembangan, Kementerian Riset, Teknologi dan
Pendidikan Tinggi Republik Indonesia
Nomor: 23/E/KPT/2019.08 Agustus 2019
https://jurnal.umk.ac.id/index.php/kredo/index

tuturan pendidik yang diujarkan dengan mematuhi prinsip kesantunan dapat berfungsi sebagai sarana pembentukan karakter peserta didik.

Berdasarkan hal-hal yang telah dibahas di atas, penelitian ini dilatarbelakangi oleh penelitian sebelumnya antara lain dilakukan oleh Zahro, Lamria, Safitri, Kusno, dan Ristiyani. Zahro (2009) memfokuskan pada upaya yang dilakukan pendidik dalam mengembangkan sosial emosional anak usia dini dengan pendekatan Beyond Centers and Circle Times. Sementara Lamria (2012) menyatakan fungsi kesantunan tindak tutur direktif yang dilakukan pendidik kepada peserta didik, peserta didik kepada pendidik ataupun antarpeserta didik. Penelitian lain dilakukan Kusno (2014) yang menyatakan bahwa seorang pendidik, kepala sekolah, peserta didik, dan seluruh pihak sekolah yang terlibat merupakan salah satu wadah bagi perkembangan kemampuan kebahasaan peserta didik dalam menghasilkan tuturan, dan aspek kesantunan berbahasa di sekolah. Pernyataan tersebut diperjelas oleh Ristiyani (2016) bahwa tuturan pengasuh yang diujarkan dengan mematuhi prinsip kesantuan pada tiap-tiap bidal dapat berfungsi sebagai sarana dalam pembentukan karakter anak-anak guna keberhasilan pembentukan karakter anakanak, dan sebagai upaya membangun pondasi demi terbentuknya sebuah peradaban bangsa yang sejahtera dan mulia.
Terkait dengan penelitian relevan yang telah diulas, menjadikan peneliti termotivasi untuk mengambil topik penelitian tersebut. Selain itu adanya ketertarikan peneliti untuk lebih lanjut membahas mengenai kesantunan pendidik dalam pembelajaran dengan peserta didik di TK Aisyiyah Bustanul Athfal XVI yang bertempat di Pasuruhan Lor Kecamatan Jati Kabupaten Kudus. Melihat realisasi maksim-maksim dalam tuturan pendidik akan memberi pemahaman bagi pendidik serta orang tua untuk meningkatkan pengetahuan dan pemahaman. Selanjutnya, hasil penelitian ini diharapkan mampu menjadi padoman bagi seluruh kalangan masyarakat agar perlu mematuhi prinsip kesantunan dalam berinteraksi dan berkomunikasi.

\section{KAJIAN TEORI}

Bidang kajian kesantunan
berbahasa dipelajari dalam pragmatik. Pragmatik adalah ilmu yang mengkaji makna tuturan. Pragmatik mengkaji makna dalam hubungannya dengan situasi ujar (Leech dalam Oka, 1993:8), sedangkan (Yule, 2006: 3) menyatakan bahwa pragmatik adalah studi tentang makna yang disampaikan oleh penutur (penulis) dan ditafsirkan oleh pendengar (pembaca). Pragmatik lebih banyak berhubungan dengan analisis tentang apa yang dimaksudkan orang dengan tuturantuturannya daripada dengan makna terpisah 


Kredo 4 (2021)
KREDO: Jurnal Ilmiah Bahasa dan Sastra
Terakreditasi Sinta 4 berdasarkan Keputusan
Direktorat Jenderal Penguatan Riset dan
Pengembangan, Kementerian Riset, Teknologi dan
Pendidikan Tinggi Republik Indonesia
Nomor: 23/E/KPT/2019.08 Agustus 2019
https://jurnal.umk.ac.id/index.php/kredo/index

dari kata atau frasa yang digunakan dalam tuturan.

Manusia sebagai makhluk sosial yang cenderung melibatkan kehidupan untuk berkomunikasi, memerlukan pemahaman mengenai faktor-faktor kesenjangan sosial. Interaksi sosial perlu melihat status relatif partisipan, yakni halhal yang berkaitan dengan usia dan kekuasaan. Jika mitra tutur merupakan orang yang lebih tua, maka diperlukan perasaan rendah hati oleh penutur. Sebaliknya, apabila mitra tutur dalam interaksi memiliki jarak yang dekat maka ada pertimbangan untuk berbicara lebih santun. Rahardi (2005:70) menyatakan bahwa makin tidak formal, makin tidak tegas, makin rendah peringkat kesejajaran maka dipastikan bahwa tuturan itu akan memiliki gradasi kesantunan yang makin tinggi jarak kesekawanannya, maka makin tinggilah gradasi kesantunan.

Brown dan Levinson (dalam Tarigan, 1987:36), menyatakan bahwa kesantunan berbahasa merupakan upaya penutur untuk "menyelamatkan muka (face-saving) lawan tutur. Artinya, bahwa kesantunan berbahasa tidak boleh membuat lawan tutur (penutur) menjadi malu. Bahasan mengenai kesantunan berbahasa dapat difokuskan pada tataran toretis dan praktis. Pada tataran teoretis, kesantunan berbahasa dapat dikaitkan dengan prinsip, kaidah, skala, dan strategi kesantunan. Prinsip tersebut dibangun berdasarkan penggunaan bahasa tertentu.
Faktor-faktor penentu yang berpengaruh dalam tindak komunikasi serta prinsip-prinsip berbahasa sangat penting dalam proses merealisasikan kesantunan berbahasa di lingkungan sekolah. Dalam hal ini peran pendidik selama pengasuhan - utamanya dalam berbahasa terhadap peserta didik mempengaruhi kesantunan berbahasanya. Leech (1983:132) menjelaskan kesantunan berbahasa berdasarkan prinsip-prinsip kesantunan. Prinsip-prinsip kesantunan merupakan prinsip yang menjelaskan bahwa di dalam penggunaan bahasa perlu memperhatikan etika dan moral.

Prinsip kesantunan (politeness principle) berkenaan dengan aturan tentang hal-hal yang bersifat sosial, estetis, dan moral dalam bertindak tutur (Grice dalam Rustono 1999:66). Konsep kesantunan bertindak tutur ada yang dirumuskan dalam bentuk kaidah, ada pula yang dijelaskan dalam bentuk formulasi strategi. Konsep kesantunan yang dirumuskan dalam bentuk kaidah membentuk prinsip kesantunan, sedangkan konsep kesantunan yang diformulasikan dalam bentuk strategi, membentuk teori kesantunan (Rustono 1999:66).

Penelitian Ristiyani (2016) yang berjudul Kesantunan Tuturan yang Digunakan Pengasuh dalam Pembentukan Karakter Anak Jalanan di Rumah Singgah, memberikan contoh bahwa kesantunan tuturan pengasuh yang diujarkan dengan mematuhi prinsip kesantuan pada tiap-tiap 


Kredo 4 (2021)
KREDO: Jurnal Ilmiah Bahasa dan Sastra
Terakreditasi Sinta 4 berdasarkan Keputusan
Direktorat Jenderal Penguatan Riset dan
Pengembangan, Kementerian Riset, Teknologi dan
Pendidikan Tinggi Republik Indonesia
Nomor: 23/E/KPT/2019.08 Agustus 2019
https://jurnal.umk.ac.id/index.php/kredo/index

maksim dapat berfungsi sebagai sarana pembentukan karakter dan sebagai upaya membangun pondasi demi terbentuknya sebuah peradaban bangsa yang sejahtera dan mulia.

Sudah sepatutnya kesantunan berbahasa mendapat perhatian baik pakar linguis, maupun para pembelajar bahasa. Selain itu, penting juga bagi setiap orang untuk memahami kesantunan berbahasa. Pada dasarnya manusia yang kodratnya adalah "makhluk berbahasa" yang senantiasa melakukan komunikasi verbal maupun nonverbal sudah sepatutnya beretika.

Refleksi untuk menilai kesantunan berbahasa dalam penggunaan sehari-hari, sangat terbilang penting. Dalam hal ini bahasa bukan hanya sebagai instrumen komunikasi, melainkan juga ajang realisasi diri yang santun. Menurut Rahardi (2005:70) kesantunan berbahasa juga dipengaruhi oleh isyarat-isyarat kinesik yang dimunculkan lewat bagian-bagian tubuh penentu, di antaranya ekspresi wajah, sikap tubuh, gerak jari-jemari, gerakan tangan, ayunan tangan, gerakan pundak, goyangan pinggul dan gelengan kepala. Isyarat-isyarat kinetik memiliki kesamaan fungsi dalam menentukan imperatif, yakni sama-sama sebagai pemertegas maksud tuturan.

Leech, 1983 (dalam Hermaji:63) menjeleskan bahwa prinsip-prinsip kesantunan merupakan prinsip yang di dalam penggunaan bahasa perlu memerhatikan etika dan moral. Leech
(1983) membedakan prinsip-prinsip kesantunan sebagai berikut.

\section{a. Maksim Kearifan (Tach Maxim)}

Gagasan dasar maksim kearifan dalam prinsip kesantunan merupakan peserta tutur hendaknya berpegang pada prinsip untuk selalu mengurangi keuntungan dirinya sendiri dan maksimalkan keuntungan pihak lain dalam kegiatan bertutur. "Semakin panjang tuturan yang diujarkan dianggap semakin santun" dan "Penggunaan tindak tutur tidak langsung dianggap lebih santun daripada tindak tutur langsung".

Contoh: (1) Tolong Susi!

(2) Tolonglah Susi!

(3) Sudilah Anda menolong Susi!

(4) Sudilah kiranya Anda menolong Susi?

(5) Kalau tidak keberatan, sudilah Anda menolong Susi?

b. Maksim Kedermawanan (Generosity Maxim)

Maksim kedermawanan atau maksim kemurahatian, para peserta turtur diharapkan dapat menghormati orang lain. Penghormatan terhadap orang lain terjadi apabila seseorang dapat mengurangi keuntungan bagi dirinya sendiri dan memaksimalkan keuntungan pihak lain.

Contoh: (1) A: Suaramu sangat bagus.

B: Saya kira hanya biasa saja seperti suara Anda juga (lebih santun). 


Kredo 4 (2021)
KREDO: Jurnal Ilmiah Bahasa dan Sastra
Terakreditasi Sinta 4 berdasarkan Keputusan
Direktorat Jenderal Penguatan Riset dan
Pengembangan, Kementerian Riset, Teknologi dan
Pendidikan Tinggi Republik Indonesia
Nomor: 23/E/KPT/2019.08 Agustus 2019
https://jurnal.umk.ac.id/index.php/kredo/index

(2) A: Suaramu sangat bagus. B: Jelas dong, saya kan keturunan penyanyi (kurang santun).

c. Maksim Permufakatan (Agreement Maxim)

Maksim permufakatan ini, ditekankan agar para peserta tutur dapat saling membina kecocokan atau kemufakatan di dalam kegiatan bertutur. Apabila terjadi kecocokan dan kemufakatan, dapat dikatakan bersikap santun.

Contoh: (1) A: Ujiannya sangat sulit sekali ya?

B: Iya, saya juga merasa kesulitan tadi, terutama soal nomor tiga (lebih santun)

(2) A: Ujiannya sangat sulit sekali ya?

B: Siapa bilang, saya bisa mengerjakan semua tadi (kurang santun).

d. Maksim Kesimpatisan (Sympath Maxim) Maksim kesimpatisan yakni, maksim yang mengharapkan agar peserta tutur dapat memaksimalkan sikap simpati antara pihak yang satu dengan pihak lainnya.

Contoh: (1) A: Kemarin saya membeli mobil baru.

B: Wah, kamu memang hebat! Selamat ya...! (lebih santun)

(2) A: Kemarin saya membeli mobil baru.

B: Beli mobil gitu aja bangga! Kemarin, ayah saya

317 | Jurnal Kredo

Vol. 4 No. 22021 juga membeli mobil.

Harganya lebih mahal! (kurang santun).

Secara umum dari teori-teori yang telah dibahas, dalam menentukan santun atau tidaknya tuturan dapat diketahui, dalam penuturan teori prinsip-prinsip kesantunan Leech cenderung dianggap paling lengkap, mapan dan relatif komprehensif. Melihat hal tersebut, prinsip kesantunan suatu tuturan dapat menjadi lebih santun dan proses komunikasipun dapat berjalan dengan lebih baik.

\section{METODE PENELITIAN}

Penelitian ini dilaksanakan di TK 'Aisyiyah Bustanul Athfal XIV Pasuruhan Lor. Subjek penelitian adalah pendidik di kelas A. Penelitian ini dikaji dengan menggunakan prinsip keilmuan pragmatik yang dicetuskan oleh Leech (1983). Penelitian ini dibuktikan secara konkret pada setiap tindak tutur yang memanfaatkan latar alami, sumber data langsung, dan peneliti sebagai instrumen utama (human instrumen).

Penelitian ini merupakan penelitian kualitatif yang bertujuan untuk mendeskripsikan bentuk kesantunan dalam interaksi pembelajaran antara pendidik dengan peserta didik. Subjek penelitian ini yakni seorang pendidik. Selanjutnya, objek penelitian ini yakni semua dialog yang berupa kata, frasa, dan atau kalimat yang dituturkan oleh pendidik pada saat 


Kredo 4 (2021)
KREDO: Jurnal Ilmiah Bahasa dan Sastra
Terakreditasi Sinta 4 berdasarkan Keputusan
Direktorat Jenderal Penguatan Riset dan
Pengembangan, Kementerian Riset, Teknologi dan
Pendidikan Tinggi Republik Indonesia
Nomor: 23/E/KPT/2019.08 Agustus 2019
https://jurnal.umk.ac.id/index.php/kredo/index

pembelajaran baik itu pelanggaran atau pematuhan maksim-maksim kesantunan

Pengumpulan data dalam penelitian ini menggunakan metode simak, yakni dengan cara menyimak penggunaan bahasa (Sudaryanto, 1993:133). Sedangkan teknik pengumpulan data yang digunakan berupa teknik simak bebas libat cakap, dalam teknik ini peneliti tidak terlibat dalam percakapan.

Peneliti hanya sebagai pemerhati apa yang dikatakan oleh responden dalam dialog. Setiap kata, frasa, dan kalimat dalam dialog antara pendidik dan peserta didik. Kemudian, kalimat yang mengandung pelanggaran ataupun pematuhan maksim kesantunan berbahasa dicatat. Selanjutnya dilakukan klarifikasi data sesuai jenis maksim yang dilanggar maupun dipatuhi.

Data yang terkumpul pada penelitian ini, terdapat dua jenis. Data pertama, berupa cuplikan hasil rekaman yang terpilih dalam pembelajaran. Data yang kedua berupa data tanggapan pendidik dan orang tua peserta didik. Tuturan tersebut melibatkan pendidik dan peserta didik, pada saat pembelajaran di kelas A TK Bustanul Athfal XVI yang digunakan sebagai tempat penelitian.

Teknik dasar yang digunakan yakni teknik Pilah Unsur Penentu (PUP). Menurut Sudaryanto (1993:21) teknik pilah unsur penentu merupakan teknik pilah di mana alat yang digunakan yakni daya pilah yang bersifat mental yang dimiliki oleh peneliti sendiri. Daya pilah ini yakni daya pilah pragmatis atau disebut metode padan pragmatis, dan alat penentunya yakni mitra tutur. Metode ini mengidentifikasi satuan kebahasaan menurut reaksi atau akibat yang terjadi di lapangan.

Instrumen yang digunakan dalam penelitian ini meliputi pedoman pengamatan untuk mengidentifikasi yang berupa rekaman dan video. Selain itu digunakan pula pedoman wawancara untuk menguatkan tanggapan pendidik dalam interaksi pengasuhan peserta didik.

Instrumen rekaman video bertujuan untuk mendapatkan data secara riil berkait situasi pembelajaran yang seharussnya. Instrumen pedoman wawancara dimaksudkan untuk memberikan gambaran riil proses berbahasa peserta didik dan pendidik dalam sebuah konteks pembelajaran. Kedua instrumen tersebut saling berkait dan melengkapi dalam memberikan data yang memadai untuk kesempurnaan penelitian. serta membentuk konteks yang lengkap.

Tabel 1. Pengamatan Tuturan Pendidik

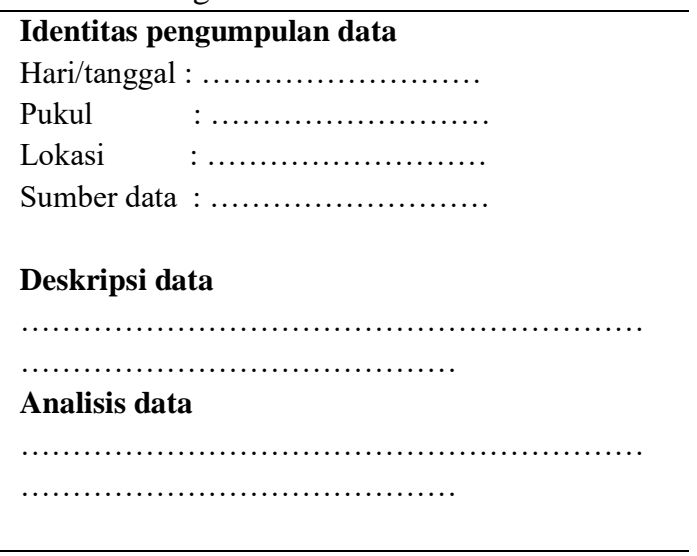




Kredo 4 (2021)
KREDO: Jurnal Ilmiah Bahasa dan Sastra
Terakreditasi Sinta 4 berdasarkan Keputusan
Direktorat Jenderal Penguatan Riset dan

Tabel 2. Lembar Pedoman Wawancara

Tanggal wawancara :

Nama informan

\begin{tabular}{lc}
\hline $\begin{array}{c}\text { Pertanyaan yang } \\
\text { diajukan kepada } \\
\text { pendidik }\end{array}$ & $\begin{array}{c}\text { Deskripsi jawaban } \\
\text { pendidik }\end{array}$ \\
\hline $\begin{array}{l}\text { Perkembangan apa sajakah } \\
\text { yang dapat dicapai peserta }\end{array}$ & $\ldots \ldots \ldots \ldots \ldots \ldots \ldots \ldots \ldots \ldots \ldots \ldots \ldots \ldots \ldots \ldots \ldots \ldots \ldots \ldots \ldots \ldots \ldots \ldots \ldots \ldots \ldots \ldots$ \\
didik dengan diterapkannya \\
$\begin{array}{l}\text { kesantunan } \\
\text { pendidik? }\end{array}$
\end{tabular}

\section{HASIL DAN PEMBAHASAN}

\section{A. Hasil Penelitian}

Tuturan pendidik dalam pembelajaran anak usia dini di TK 'Aisyiyah Bustanul Athfal XIV merupakan proses tindak tutur antara pendidik dengan peserta didik (penutur dan mitra tutur) yang merupakan pematuhan prinsip kesantunan. Pematuhan prinsip kesantunan dapat terjadi apabila pendidik mematuhi prinsip kesantunan Leech (1983).

Tuturan pendidik dalam bentuk kesantunan berbahasa pada pembelajaran mematuhi prinsip kesantunan pada maksim kesantunan Leech (1983), yakni (1) maksim kearifan (Tach Maxim), (2) maksim kedermawanan (Generosity Maxim), (3) maksim permufakatan (Agreement Maxim), (4) maksim kesimpatisan (Sympath Maxim).

\section{a. Maksim Kearifan (Tach Maxim) \\ Pada tuturan (1) yang disampaikan} pendidik terhadap peserta didik saat pembelajaran di kelas A adalah ketika peserta didik menangis dan pendidik berusaha menenangkan serta mengondisikan pembelajaran. Tidak terjadi percakapan antara pendidik dan peserta didik, akan tetapi pendidik bertutur kepada peserta didik dengan bijak. Berikut tuturan pendidik:

(1) Konteks : pendidik meminta peserta didik untuk duduk dan berdoa

Pendidik : :Mas Yubi sini lho, sini jaga jarak. Ke sana dikit, ke sana dikit. Mas Haski lihat sana. Yok mulai lagi."

A'udzu billahi minasy syaithonir rojiim

Bismillahirrahmanirrahim

"Silakan duduk sayang, Mas Yubi berdoa dulu."

Tuturan (1) menunjukkan penggunaan bahasa yang santun dalam interaksi pembelajaran pendidik terhadap peserta didik. Bahasa yang santun ditunjukkan oleh penggunaan tuturan "Silakan duduk sayang". Hal tersebut disebabkan oleh tuturan pendidik yang berusaha mengurangi rasa kekecewaan atau mengapresiasi peserta didik yang sudah mau mengikuti pembelajaran meskipun belum sepenuhnya mengikuti secara tertib. Tuturan tersebut memperhalus bahasa yang digunakan sehingga kesan tuturan pendidik data (1) tidak menekan atau memojokkan peserta didik. 


Kredo 4 (2021)
KREDO: Jurnal Ilmiah Bahasa dan Sastra
Terakreditasi Sinta 4 berdasarkan Keputusan
Direktorat Jenderal Penguatan Riset dan
Pengembangan, Kementerian Riset, Teknologi dan
Pendidikan Tinggi Republik Indonesia
Nomor: 23/E/KPT/2019.08 Agustus 2019
https://jurnal.umk.ac.id/index.php/kredo/index

Bahasa yang santun dalam interaksi pendidik terhadap peserta didik menaati maksim kearifan. Maksim kearifan atau kebijaksanaan (Tach Maxim) merupakan kaidah yang mengharuskan setiap pendidik untuk meminimalkan kerugian orang lain, atau memaksimalkan keuntungan bagi orang lain. Tuturan pendidik ke peserta didik yang mengatakan bahwa "Silakan duduk sayang." merupakan bahasa santun yang meminimalkan kerugian peserta didik, atau memaksimalkan keuntungan peserta didik. Kerugian peserta didik yang dimaksud adalah rasa kekecewaan atau rasa tidak senang dalam mengikuti pembelajaran yang sedang berlangsung.

(2)Konteks : peserta didik yang salah masuk kelas

Pendidik : : Ayok, mas Dzaka gak usah nangis, di kasih tahu bu Guru sebelum berdoa dikasih namanya

Face Shiled. Apa Mbak Shila?"

Peserta didik : "Face Shiled."

Pendidik : "dipakai di sekolahan, nanti kalau udah selesai ditaruh sana lagi, besok kalau sekolah dipakai lagi ya, yang ngasih mamanya Mbak Luna. Kalau pakai ini (face shiled) gak pakai masker gakpapa. Mas Dzaka itu temannya ada yang nangis gak ya? Endak. Lho ini Mas Diandra. Lho sopo iki? Salah. Masuk kelas B kamu.

Tuturan (2) yang diucapkan pendidik terjadi saat ada peserta didik yang salah masuk dalam kelas sehingga pendidik merasa tidak seharusnya peserta didik tersebut masuk dalam kelasnya. Tuturan (2) menunjukkan penggunaan bahasa yang tidak santun dalam memerintah peserta didik yang salah masuk ke dalam kelasnya. Tuturan tersebut melanggar maksim kearifan. Maksim kearifan adalah kaidah yang menuntun penutur untuk mengurangi kerugian atau menambah keuntungan mitra tutur. Namun, pada data (2) tuturan pendidik ke peserta didik justru menambah kerugian, sehingga peserta didik tersebut malu dan bingung karena salah masuk kelas.

b. Maksim Kedermawanan (Generosity Maxim)

Data (3) pendidik bertutur terhadap peserta didik saat mengerjakan tugasnya. Berikut peristiwa tutur yang terjadi.
(3)Konteks : peserta didik yang tidak membawa lem 


\section{Kredo 4 (2021) \\ KREDO: Jurnal Ilmiah Bahasa dan Sastra Terakreditasi Sinta 4 berdasarkan Keputusan Direktorat Jenderal Penguatan Riset dan Pengembangan, Kementerian Riset, Teknologi dan Pendidikan Tinggi Republik Indonesia Nomor: 23/E/KPT/2019. 08 Agustus 2019 https://jurnal.umk.ac.id/index.php/kredo/index}

Pendidik : Mas Haski gak ada lem? Lemnya gak ada? Tak ambilin lem ya. Tak ambilkan lem dulu. Dikasih satu-satu di rumah do ora mbalik.

Tak carikan dulu mas Haski.

Mas haski ini lemnya. Lemnya di rumah ya?

Kasih lem lagi gakpapa nanti cuci tangan.

Dikit-dikit aja gak perlu banyabanyak. Lha Pinter.

Interaksi dari pendidik yang terjadi (3) yakni ketika pembelajaran berlangsung pendidik melihat salah satu peserta didiknya ada yang tidak membawa lem kertas. Sebagai seorang pendidik, dengan rasa rendah hati pendidik mengambilkan lem untuk peserta didiknya. Bahasa yang digunakan Tak carikan dulu mas Haski. Mas Haski ini lemnya. Lemnya di rumah ya?... menggunakan bahasa yang santun karena menaati maksim kedermawanan, yakni menambah kerugian diri sendiri atau mengurangi keuntungan diri sendiri. Menambah kerugian yang dimaksud yakni pendidik membebani dirinya untuk mengambilkan lem, meskipun peserta didik sudah diberi lem tetapi tidak dibawa.

Tuturan (4) juga terjadi saat pendidik melihat salah satu peserta didiknya belum menyobek-nyobek kertas korannya. Adapun tuturannya sebagai berikut.

(4)Konteks : pendidik membantu menyobek-nyobek kertas

Pendidik $\quad$ Yok, kertasnya
disobek-sobek dek.
Yok, Mas Yubi
kertasnya disobek-
sobek. Disobek-
sobek dulu ya.
Bu guru bantu.
Eem.. Pinternya.
Nempelnya pakai
lem ini. Siip pinter!
Kok panjang-
panjang, bisa kecil-
kecil ndak? Yok
dikit-dikit yok
menempelnya.

Interaksi pendidik ke peserta didik yang terjadi (4) yakni ketika pembelajaran berlangsung pendidik melihat salah satu peserta didiknya ada yang belum menyobek-nyobek kertas korannya. Sebagai seorang pendidik, dengan rasa rendah hati pendidik membantu menyobeknyobekkan kertas koran peserta didiknya. Bahasa yang digunakan Yok, Mas Yubi kertasnya disobek-sobek. Disobek-sobek dulu ya. Bu guru bantu... menggunakan bahasa yang santun karena menaati maksim kedermawanan, yakni menambah kerugian diri sendiri atau mengurangi keuntungan diri sendiri. Menambah kerugian yang dimaksud yakni pendidik membebani dirinya untuk membantu peserta didik yang belum menyobek-nyobek kertas korannya. 


Kredo 4 (2021)
KREDO: Jurnal Ilmiah Bahasa dan Sastra
Terakreditasi Sinta 4 berdasarkan Keputusan
Direktorat Jenderal Penguatan Riset dan
Pengembangan, Kementerian Riset, Teknologi dan
Pendidikan Tinggi Republik Indonesia
Nomor: 23/E/KPT/2019.08 Agustus 2019
https://jurnal.umk.ac.id/index.php/kredo/index

c. Maksim Permufakatan (Agreement Maxim)

Pada tuturan (5) terjadi peristiwa tutur antara pendidik dan peserta didik. Peserta didik menjawab atau menanggapi pendidik. Berikut peristiwa tutur yang terjadi.

(5)Konteks
rumah

pendidik : "artinya: $A k u$

bersaksi bahwa tiada Tuhan selain

Allah dan aku bersaksi bahwa Nabi

Muhammad adalah utusan Allah.

Pinter, kemarin anak-anak libur

berapa lama ya? Di rumah dikasih

bahan belajar bu guru. Siapa yang

belajar di rumah?"

Peserta didik : "Aku"

Pendidik : Siapa ya yang gak

mau belajar? Mas Haski mau belajar gak di rumah?

Peserta didik : "Mau"

Interaksi pembelajaran dalam kelas terjadi ketika pendidik bertanya kepada peserta didik mengenai belajar di rumah. Hal tersebut dilakukan pendidik setelah membaca doa sebelum belajar. Pendidik bertanya dan peserta didik menanggapi pertanyaan yang ditanyakan pendidik. Bahasa yang digunakan pendidik, kemarin anak-anak libur berapa lama ya? Di rumah dikasih bahan belajar bu guru. Siapa yang belajar di rumah? Siapa ya yang gak mau belajar? Mas Haski mau belajar gak di rumah?... Bahasa yang digunakan tersebut santun karena menaati maksim permufakatan, yakni saling membina kecocokan atau kemufakatan di dalam kegiatan bertutur. Pada data (5) terjalin kecocokan antara peserta didik dan pendidik yang bertanya dan menerima jawaban dengan baik dari peserta didiknya.

Pada tuturan (6) terjadi peristiwa tutur antara pendidik dan peserta didik. Pendidik bertanya dan peserta didik menjawab atau menanggapi. Berikut peristiwa tutur yang terjadi.

(6)Konteks : peserta didik mengumpulkan tugas yang belum dikerjakan

Pendidik :"Mas $\quad$ Yubi bukunya ditumpuk kok masih kosong? Belajar gak ya di rumah?"

Peserta didik : :Endak"

Pendidik :"Endak kenapa?

Endak belajar sama kak Ema? Sama Mama? Habis ini belajar ya. Mas, mas Haski tepuk dulu ya."

Interaksi pengasuhan pembelajaran dalam kelas terjadi ketika pendidik bertanya kepada peserta didik mengenai buku yang dikumpulkannya masih kosong dan tugasnya belum diselesaikan.

Hal tersebut dilakukan pendidik untuk mengecek apakah peserta didik mau belajar atau tidak saat di rumah. Pendidik bertanya dan peserta didik menanggapi pertanyaan yang ditanyakan pendidik. 


Kredo 4 (2021)
KREDO: Jurnal Ilmiah Bahasa dan Sastra
Terakreditasi Sinta 4 berdasarkan Keputusan
Direktorat Jenderal Penguatan Riset dan
Pengembangan, Kementerian Riset, Teknologi dan
Pendidikan Tinggi Republik Indonesia
Nomor: 23/E/KPT/2019.08 Agustus 2019
https://jurnal.umk.ac.id/index.php/kredo/index

Bahasa yang digunakan pendidik, Mas Yubi bukunya ditumpuk kok masih kosong? Belajar gak ya di rumah?... Bahasa yang digunakan tersebut santun karena menaati maksim permufakatan, yakni saling membina kecocokan atau kemufakatan di dalam kegiatan bertutur. Pada data (6) terjalin kecocokan antara peserta didik dan pendidik yang bertanya dan menerima jawaban dengan baik dari peserta didiknya.

\section{d. Maksim Kesimpatisan (Sympath Maxim)}

Pada tuturan (7) terjadi peristiwa tutur antara pendidik dan peserta didik. Pendidik memberikan simpati terhadap peserta didik pada saat pembelajaran berlangsung. Berikut peristiwa tutur yang terjadi

(7) Konteks : pendidik memberikan pernyataan

Mengenai suara peserta didik

Pendidik : "Biasanya Mbak Shila suaranya bagus. Ini baru pertama masuk, makanya suaranya masih di sini semua (menunjuk tenggorokan). Yok suaranya dikeluarin."

Pada data (7) terjadi interaksi pengasuhan pembelajaran dalam kelas terjadi ketika pendidik memberikan simpati kepada peserta didik mengenai kepeduliannya akan suara peserta didik yang suaranya pelan-pelan. Hal tersebut 323 | Jurnal Kredo

Vol. 4 No. 22021 dilakukan pendidik untuk memberikan rasa kepedulian atau simpati kepada peserta didik sehingga peserta didik tidak merasa sungkan lagi untuk mengeluarkan suaranya.

Adapun pernyataan bahasa yang digunakan pendidik, Biasanya Mbak Shila suaranya bagus. Ini baru pertama masuk, makanya suaranya masih di sini semua (menunjuk tenggorokan). Yok suaranya dikeluarin. Bahasa yang digunakan tersebut santun karena menaati maksim kesimpatisan. Maksim kesimpatisan yakni kaidah bahasa santun yang menurut para peserta tutur memaksimalkan simpati kepada pihak mitra tutur. Penggunaan ungkapan biasanya $\mathrm{Mb}$ Shila suaranya bagus pada data (7) menunjukkan sikap simpati pendidik terhadap peserta didiknya.

Pada tuturan (8) terjadi peristiwa tutur antara pendidik dan peserta didik. Pendidik memberikan simpati terhadap peserta didik pada saat pembelajaran berlangsung. Berikut peristiwa tutur yang terjadi

(8) Konteks : : pendidik menenangkan hati peserta didik Pendidik : "Mas Dzaka, itu tadi nangis gak diantar papa. Sekarang ngerjain sendiri pinter Mas Dzaka. Besok gak nangis lagi ya."

Pada data (8) terjadi interaksi pengasuhan pembelajaran dalam kelas 


Kredo 4 (2021)
KREDO: Jurnal Ilmiah Bahasa dan Sastra
Terakreditasi Sinta 4 berdasarkan Keputusan
Direktorat Jenderal Penguatan Riset dan
Pengembangan, Kementerian Riset, Teknologi dan
Pendidikan Tinggi Republik Indonesia
Nomor: 23/E/KPT/2019.08 Agustus 2019
https://jurnal.umk.ac.id/index.php/kredo/index

terjadi ketika pendidik memberikan simpati kepada peserta didik mengenai kepeduliannya terhadap peserta didik yang tidak nangis dan mau mengerjakan tugasnya. Hal tersebut dilakukan pendidik untuk memberikan rasa kepedulian atau simpati kepada peserta didik, sehingga peserta didik tidak merasa tenang dan beharap besok ketika sekolah tidak menangis lagi. Adapun pernyataan bahasa yang digunakan pendidik, Mas Dzaka, itu tadi nangis gak diantar papa. Sekarang ngerjain sendiri pinter Mas Dzaka. Besok gak nangis lagi ya.

Bahasa yang digunakan tersebut santun karena menaati maksim kesimpatisan. Maksim kesimpatisan yakni Kaidah bahasa santun yang menurut para peserta tutur memaksimalkan simpati kepada pihak mitra tutur. Penggunaan ungkapan Sekarang ngerjain sendiri pinter Mas Dzaka.pada data (9) menunjukkan sikap simpati pendidik terhadap peserta didiknya.

\section{B. Pembahasan}

Maksim kearifan atau kebijaksanaan

(Tach Maxim) terlihat jelas pada percakapan awal pembelajaran di TK ABA XIV yang mengharuskan setiap pendidik mengaplikasikan kesantunan kebahasaan dalam bertutur saat memulai pembelajaran. Terkandung maksud bahwa sebuah prosedur besar dalam memulai mendidik dan membelajarkan peserta didik pada saat pembelajaran dengan sepenuhnya terlibat di dalamnya. Sebagaimana yang dijelaskan oleh Rahardi (2008:104) bahwa penanda kesantunan lazimnya menggunakan penanda kesantunan silakan. Penanda kesantunan silakan sudah seringkali diterapkan oleh pendidik TK ABA XIV dengan tujuan memperhalus ataupun mempersantun tuturan.

Pada pembelajaran daring, maksim kearifan sangat diperlukan. Hal ini mengingat situasi pembelajaran yang mengharuskan untuk bertemu dalam situasi pembelajaran yang berbeda. Aplikasinya, pendidik tetap memperhatikan kebijaksanaan yang sekaligus merupakan kearifan -Tach Maxim Nilai didik yang disampaikan mulia. Penyampaiannya juga dengan cara mulia-melalui kesantunan berbahasa. Dengan maksim kearifan diharapkan sekali peserta didik memulai kegiatan dengan support dan motivasi tinggi. Hal ini membiasakan peserta didik untuk arif dalam bertutur bahasa dan bertindak dalam keseharian.

Maksim kedermawanan (Generosity Maxim) tergambarkan pada kegiatan pembelajaran berikutnya saat peserta didik hendak menggunakan lem untuk kegiatan pembelajaran-kegiatan menempel. Pendidik yang memberi keteladanan berupa contoh tergambarkan melalui sikap menutup kekecewaan peserta didik yang tidak membawa lem karena tertinggal dengan bertindak tutur yang santun. Tidak menuntut peserta didik untuk pulang dan mengambilnya.

Rahardi (2005:26) menyatakan bahwa kesantunan tuturan sesungguhnya 


Kredo 4 (2021)
KREDO: Jurnal Ilmiah Bahasa dan Sastra
Terakreditasi Sinta 4 berdasarkan Keputusan
Direktorat Jenderal Penguatan Riset dan
Pengembangan, Kementerian Riset, Teknologi dan
Pendidikan Tinggi Republik Indonesia
Nomor: 23/E/KPT/2019.08 Agustus 2019
https://jurnal.umk.ac.id/index.php/kredo/index

juga dapat dilihat dari banyak sedikitnya tuturan itu memberikan pilihan kepada mitra tutur. Hal tersebut menunjukkan bahwa ketidaksantunan tersebut menggandung imperatif yang berdampak negatif pada perasaan peserta didik. Sebuah pembelajaran kesantunan yang terwujud pada pembelajaran anak usia dini melalui maksim ini.

Pada pembelajaran daring maksim kedermawanan lebih dibutuhkan dan disempurnakan agar pembelajaran menjadi utuh dan menyenangkan. Situasi peserta didik yang bertemu dengan pendidiknya hanya melalui video membuat kesan yang mendalam untuk setidaknya mengobati kekurangdermawanan. Maksim ini sangat menyentuh dan memberi kesan yang mendalam dalam percakapan antara pendidik dan peserta didik.

Maksim permufakatan (Agreement Maxim) terlihat pada saat pendidik mengonfirmasi kegiatan peserta didik di rumah. Masih bersedia belajar di rumah ataukah tidak bersedia. Terjadi kemufakatan antara pendidik dan peserta didik dalam menyelesaikan masalah dalam pembelajaran di TK. Peserta didik terarah dengan kesantunan berbahasa maksim permufakatan ini. Peserta didik tanpa menyadari terobsesi dan terbawa kembali kepada konsep pembelajaran yang disampaikan pendidiknya.

Pada pembelajaran daring maksim permufakatan terkesan sangat dibutuhkan untuk membina kelancaran berkomunikasi mendukung proses belajar mengajar.
Komunikasi dengan tawar-menawar berupa saling memahami kondisi yang timbul saat pembelajaran sangat penting. Tidak sekadar menjelaskan makna yang disampaikan namun lebih pada tataran pemahaman konteks pembicaraan yang sarat dengan makna.

Maksim kesimpatisan (Sympath Maxim) tergambarkan pada kesantunan berbahasa saat pendidik membersamai peserta didik pada kegiatan pembelajaran terjadwal. Turut sertanya pendidik terlibat penuh dan kesantunan berbahasa yang digunakan untuk memotivasi peserta didik yang tidak mau berbicara merupakan alur positif dalam menyampaikan kesimpatisan. Maksim ini terpenuhi secara maksimal pada pembelajaran di TK Aisyiyah Bustanul Atfhal XIV. Hal tersebut sesuai dengan pernyataan Rahardi (2005:66) bahwa upaya masyarakat untuk menjunjung rasa simpati terhadap orang lain merupakan bentuk kesantunan.

\section{PENUTUP}

\section{Simpulan}

Kesantunan tuturan pendidik terdapat maksud, bahwa sebuah prosedur besar dalam memulai mendidik dan membelajarkan peserta didik pada saat pembelajaran dengan sepenuhnya terlibat didalamnya. Nilai didik yang disampaikan mulia. Penyampaiannya juga dengan cara mulia-melalui kesantunan berbahasa. Dengan maksim kearifan diharapkan sekali peserta didik memulai kegiatan dengan

\section{5 | Jurnal Kredo}




Kredo 4 (2021)
KREDO: Jurnal Ilmiah Bahasa dan Sastra
Terakreditasi Sinta 4 berdasarkan Keputusan
Direktorat Jenderal Penguatan Riset dan
Pengembangan, Kementerian Riset, Teknologi dan
Pendidikan Tinggi Republik Indonesia
Nomor: 23/E/KPT/2019.08 Agustus 2019
https://jurnal.umk.ac.id/index.php/kredo/index

support dan motivasi tinggi. Hal ini membiasakan peserta didik untuk arif dalam bertutur bahasa dan bertindak dalam keseharian.

Pada pembelajaran daring maksim kesimpatisan sangat diperlukan untuk mengondisikan peserta didik dalam menerima motivasi dari pendidik untuk keberlangsungan pembelajaran. Kesantunan dalam berkomunikasi dengan sikap pendidik yang membersamai peserta didik dapat tercipta maksim kesimpatisan secara utuh.

Bedasarkan hasil analisis data penelitian, dapat diambil simpulan bahwa secara keseluruhan tuturan pendidik memenuhi prinsip-prinsip kesantunan pada setiap maksim kesantunan. Hasil dari observasi dan wawancara di lapangan baik dengan pendidik maupun wali peserta didik, bahwa kesantunan berbahasa pendidik sangat berpengaruh bagi perkembangan berbahasa peserta didik Di antara wujud peserta didik yang santun yakni ketika bertutur dengan kedua orang tuanya tidak berkata kasar dan cenderung patuh.

Tuturan pendidik dalam kesantunan berbahasa pada pembelajaran mematuhi prinsip-prinsip kesantunan di tiap maksimnya. Hal tersebut merupakan bentuk aplikasi pendidik untuk menerapkan kesantunan berbahasa dalam pengasuhan di TK 'Aisyiyah Bustanul Athfal XIV. Dari paparan ini, bahwa pendidik yang santun menjadikan peserta didik santun, pendidik yang mengimplementasikan kesantunan berbahasa menjadikan peserta didik santun dalam berbahasa.

\section{Saran}

Setiap maksim dalam prinsipprinsip kesantunan Leech (1983) memiliki fungsi yang dapat dijadikan sebagai sarana memaksimalkan tuturan pendidik untuk lebih santun, sehingga anak usia dini bisa maksimal dalam memperoleh pembelajaran.

Konsep kesantunan berbahasa diharapkan dapat menjadi pembelajaran di sekolah formal maupun nonformal agar setiap orang mampu mengaplikasikan di lingkungannya. Selanjutnya, dalam rangka untuk menyukseskan pendidikan hendaknya seorang pendidik memerhatikan kesantunan berbahasa saat berinteraksi dengan peserta didik.

Berdasarkan hasil dari temuan penelitian ini, saran dari peneliti yakni, dalam meningkatkan kualitas kesantunan berbahasa peserta didik, utamanya di Taman Kanak-kanak harus selalu ditingkatkan. Pada dasarnya, anak usia dini sangat bergantung pada pendidik yang diibaratkan sebagai orangtua ke dua saat berada di sekolah. 


Kredo 4 (2021)
KREDO: Jurnal Ilmiah Bahasa dan Sastra
Terakreditasi Sinta 4 berdasarkan Keputusan
Direktorat Jenderal Penguatan Riset dan
Pengembangan, Kementerian Riset, Teknologi dan
Pendidikan Tinggi Republik Indonesia
Nomor: 23/E/KPT/2019. 08 Agustus 2019
https://jurnal.umk.ac.id/index.php/kredo/index

\section{DAFTAR PUSTAKA}

Hermaji, Bowo. 2016 Teori Pragmatik. Yogyakarta: Magnum Pustaka Utama.

Keraf, G. 1973. KOMPOSISI Sebuah Pengantar Kemahiran Bahasa. Nusa Indah: Ende.

Kusno, Ari. 2014. "Kesantunan Linguistik Kalimat Imperatif oleh Pendidik dan Pengasuh kepada Peserta Didik di Taman Penitipan Anak (TPA) Sanggar Rubinha Samarinda”. Jurnal Bahasa, Sastra dan Pembelajarannya, 4 (2) hal. 149-162.

Lamria, Mei. 2012. "Kesantunan Verbal dan Nonverbal pada Tuturan Direktif dalam Pembelajaran di SMP Taman Rama National Plus Jimbaran”. Skripsi. Bali: Program Studi Bahasa Indonesia Pascasarjana Universitas Pendidikan Ganesha

Leech, Geoffrey. 1993. Prinsip-prinsip Pragmatik. Jakarta: Universitas Indonesia.

Nurjamily, Wa Ode. 2015. "Kesantunan Berbahasa Indonesia dalam Lingkungan Keluarga". Jurnal Humanika 5 (3).

Rahardi, Kunjana. 2005. Pragmatik Kesantunan Imperatif Bahasa Indonesia. Jakarta: Erlangga.

Ristiyani. 2016. "Kesantunan Tuturan yang Digunakan Pengasuh dalam Pembentukan Karakter Anak Jalanan Di Rumah Singgah”. Jurnal Refleksi Edukatika, 6 (2).

Rustono. 1999. Pokok-pokok Pragmatik. Semarang: Semarang: IKIP Semarang Press.

Subyantoro. 2008. Pelangi Pembelajaran Bahasa Tinjauan Semata Burung Psikolinguistik. Semarang: UNNES Press

Sudaryanto. 2015. Metode dan Aneka Teknik Analisis Bahasa. Yogyakarta: Duta Wacana University Press.

Safitri, Kurnia. 2014. "Penyimpangan Prinsip Kesantunan Berbahasa dalam Interaksi Belajar Mengajar Bahasa Indonesia Siswa Kelas VII SMP Negeri 3 Sawon”. Skripsi. FBS Universitas Negeri Yogyakarta.

Yule, George. 1996. Pragmatik. Yogyakarta: Pustaka Pelajar.

Zahro, Siti U. 2009. "Upaya Pendidik dalam Mengembangkan Sosial-Emosional Anak Usia Dini dengan Pendekatan Beyond Centers and Circle Times (Kasus di TK Islam Modern Al-Furqon Yogyakarta". Skripsi. Yogyakarta: PAI Universitas Islam Negeri Sunan Kalijaga Yogyakarta. 


Kredo 4 (2021)
KREDO: Jurnal Ilmiah Bahasa dan Sastra
Terakreditasi Sinta 4 berdasarkan Keputusan
Direktorat Jenderal Penguatan Riset dan
Pengembangan, Kementerian Riset, Teknologi dan
Pendidikan Tinggi Republik Indonesia
Nomor: 23/E/KPT/2019.08 Agustus 2019
https://jurnal.umk.ac.id/index.php/kredo/index

Zamzani, dkk. 2011. "Pengembangan Alat Ukur Kesantunan Bahasa Indonesia dalam Interaksi Sosial Bersemuka dan Non Bersemuka". Jurnal Litera, 10 (1): 35-50. 